\title{
Optimalisasi keterampilan merajut sebagai solusi peningkatan ekonomi warga saat pandemi
}

\section{Adi Sumarsono ${ }^{1 *}$, Siti Nurleha ${ }^{2}$, Dicha Ummi Khasanah ${ }^{3}$, Novia Natasya Wardani $^{4}$, Wahyuni ${ }^{5}$, Sriyani ${ }^{6}$, Dewi Listiani ${ }^{7}$, Kasmawati ${ }^{8}$}

${ }^{1}$ Universitas Musamus, Merauke, Inodonesia, email: adi@unmus.ac.id

2Universitas Musamus, Merauke, Inodonesia, email: sitinurleha071001@gmail.com

${ }^{3}$ Universitas Musamus, Merauke, Inodonesia, email: dichaummi@gmail.com

${ }^{4}$ Universitas Musamus, Merauke, Inodonesia, email: natasyanovia06@gmail.com

5Universitas Musamus, Merauke, Inodonesia, email: wahyuni230621@gmail.com

${ }^{6}$ Universitas Musamus, Merauke, Inodonesia, email: sriyani00@gmail.com

${ }^{7}$ Universitas Musamus, Merauke, Inodonesia, email: dewilisti@gmail.com

${ }^{8}$ Universitas Musamus, Merauke, Inodonesia, email: kasmawati@gmail.com6

*Koresponden penulis

\section{Info Artikel}

Diajukan: 21 Des 2020

Diterima: 06 Mei 2021

Diterbitkan: 28 Mei 2021

Keywords:

knitting; economic

improvement

Kata Kunci:

merajut; peningkatan

ekonomi

Lisensi:

cc-by-sa

\begin{abstract}
The pandemic of the spread of Covid 19 has an impact on all areas, one of which is the family economy. The purpose of this service includes two things, namely assisting the community to recognize and make types of skills in the form of knitting, and to produce products which are then marketed to improve the economy of the community. This service activity method is carried out in three ways, namely training, implementation and mentoring. The subjects of this service activity are members of the community, especially housewives in Rimba Jaya Village in Merauke Regency. The results of this activity include two things, first, the partner community has experienced an increase in knowledge, understanding and skills in knitting by 39.3 percent and an increase in partner skills in the form of bag knitting types, mask models, mask connector models, and hats. and songkok. Second, the products that have been produced have begun to be marketed through online media in Merauke Regency. The achievement of this service is very dependent on the consistency of the spirit of partners to work during a pandemic and becomes the second choice after activities as a farmer.
\end{abstract}

\section{Abstrak}

Pandemi Covid 19 berdampak pada semua bidang, termasuk bidang ekonomi keluarga. Tujuan kegiatan pengabdian adalah melakukan proses pendampingan masyarakat untuk mengenal dan membuat keterampilan merajut, dan menghasilkan produk yang dapat dipasarkan untuk meningkatkan ekonomi warga masyarakat. Kegiatan pengabdian ini dilaksanakan melalui tiga cara yaitu pelatihan, penerapan dan pendampingan. Subjek kegiatan pengabdian ini adalah ibu-ibu rumah tangga Desa Rimba Jaya Kabupaten Merauke. Hasil capaian dari kegiatan ini meliputi dua hal yaitu pertama, masyarakat mitra mengalami peningkatan dalam hal pengetahuan, pemahaman dan keterampilan dalam merajut sebesar 39,3 persen dan tercapainya peningkatan keterampilan mitra yang berupa jenis rajutan model tas, model masker, model penyambung masker, serta topi dan songkok. Kedua, produk yang sudah dihasilkan sudah mulai dipasarkan melalui media online di Kabupaten Merauke. Ketercapaian 
dari kegiatan pengabdian ini sangat bergantung dari konsistensi semangat mitra untuk berkarya disaat pandemi serta menjadi pilihan kedua setelah beraktifitas sebagai petani.

\section{PENDAHULUAN}

Dampak luas dari situasi saat pandemi Covid 19 sangat dirasakan oleh seluruh lapisan masyarakat. Berbagai bidang yang terkena dampak dari merebaknya kasus penyebaran virus di tahun 2019 hingga 2020 mengakibatkan banyak warga masyarakat yang mulai merasakan khususnya dibidang ekonomi keluarga. Peran aktif masyarakat dalam menerapkan protokol kesehatan dilaksanakan beriringan dengan tetap melanjutkan kegiatan sehari-hari guna mencukupi kebutuhan dasar hidup dan menjamin keberlangsungan hidup. Penyebaran dari Covid 19 yang sudah hampir menyerang warga dunia, tidak terkecuali warga masyarakat yang ada di negara Indonesia. Virus Corona (Covid 19) sangat mudah menyebar dan menginfeksi manusia, serta menularkannya secara mudah melalui kegiatan kontak dengan penderita (Mona, 2020).

Penyebaran virus disaat pandemi ini sangat dirasakan oleh banyak kalangan, keberadaan warga masyarakat khususnya di Kabupaten Merauke juga berdampak data dari satgas penanganan covid 19 yang menyebutkan pada bulan Agustus 2020 terdapat lima orang suspeck (http://covid19.merauke.go.id/). Keberadaan ekonomi keluarga khususnya masyarakat berdampak pada kualitas serta kuantitas dalam memenuhi kebutuhan dasar hidup. Warga masyarakat yang ada di kampung Wasur, Desa Rimba Jaya Kabupaten Merauke sebagian besar menjalani aktivitas sebagai petani dan pengrajin batu bata. Bagi ibu-ibu yang membantu suami dalam memenuhi kebutuhan terkadang menyisakan waktu luang yang banyak. Saat menunggu hasil panen dan saat musim kemarau tiba, banyak dari ibu-ibu yang membutuhkan aktivitas tambahan guna menambah keterampilan dalam membantu suami.

Hasil observasi yang telah dilaksanakan sebelum kegiatan ini dilaksanakan didapatkan informasi melalui pengamatan dan wawancara langsung kepada warga masyarakat bahwa hal yang menjadi permasalahan dalam menunjang kebutuhan hidup disaat pandemi salah satunya adalah penunjang aktivitas tambahan guna menunjang efektivitas hidup yang lebih bermanfaat. Berdasarkan wawancara kepada ibu-ibu warga kampung Wasur di Kabupaten Merauke, didapatkan informasi bahwa perlunya tambahan keterampilan saat mengisi waktu kosong. Penambahan kegiatan yang produktif dapat menambah khazanah ilmu baru dan juga dapat menunjang tambahan ekonomi warga masyarakat.

Berdasarkan dari hasil analisis yang mendalam, didasarkan dengan kajian litelatur serta analisis situasi dari keberadaan mitra maka, tim yang tergabung dari Himpunan Mahasiswa Jurusan Pendidikan Matematika Universitas Musamus yang terdiri dari sepuluh orang mahasiswa memberikan solusi dengan melaksanakan program pengabdian masyarakat sebagai aktualisasi ilmu berupa pendampingan keterampilan merajut yang bertujuan 
untuk menambah pengetahuan dan juga keterampilan serta produk yang sudah dihasilkan dapat menambah masukan ekonomi warga masyarakat itu sendiri. Kegiatan yang juga mendapat pendanaan dari program PHP2D ini langsung dilaksanakan dengan fokus kegiatan melalui pengabdian masyarakat.

Banyak sekali hal yang dapat dilakukan selama mengisi waktu luang secara positif disaat terjadinya pandemi ini. Selain dibatasi dengan kegiatan yang terbatas dan dilakukan dengan cara yang tidak leluasa, kegiatan positif dapat dilaksanakan dengan mengaktualisasikan keahlian salah satunya dengan merajut. Merajut adalah seni tradisional mengaitkan benang dengan pola-pola rajut yang menghasilkan hasil karya seni tertentu (Utami \& Hidayah, 2019) (Utami \& Hidayah, 2019). Melalui kegiatan merajut selain sebagai kegiatan mengisi waktu luang dengan hal yang positif juga dapat dilakukan guna meningkatkan suasana hati. Kegiatan positif yang dapat dilakukan dengan cara berkegiatan merajut ternyata juga dapat memberikan peningkatan positif dalam pikiran seseorang dalam bentuk peningkatan suasana hati (mood) (Masiah \& Adawiyah, 2020).

Hal yang khas dengan kegiatan aktivitas merajut dilakukan secara manual oleh jari dan dilakukan sesuai teknik tertentu. Hasil dari rajutan akan menghasilkan produk yang asli yang tidak dikerjakan dalam jumlah besar dalam waktu bersamaan seperti dengan menggunakan mesin pabrik. Rajutan merupakan produk hand made (buatan tangan) yang dapat dijadikan solusi dalam berpenampilan sebagai alat pelengkap yang dapat mencirikan khas dari penampilan penggunanya sendiri (Rosdiana, 2018). Kegiatan positif dapat dilakukan oleh ibu-ibu rumah tangga dengan mengedepankan kerjasama dengan kemampuan diri sendiri serta ditopang dengan keahlian dalam mengolah benang sesuai dengan pola yang diinginkan. Proses rajutan yang dapat dilakukan dalam jumlah banyak tidak sama jika dibandingkan dengan hasil produksi industri, akan tetapi kelebihan dari hasil rajutan dapat memberikan warna dan keistimewaan sendiri bagi penggunanya (Vanda et al., 2015). Melalui kegiatan pendampingan kepada masyarakat ini diharapkan lebih membuka peluang dan dapat memberikan kemampuan dan keterampilan bagi mitra pengabdian.

Usaha pengabdian kepada masyarakat yang sudah dilaksanakan menimbulkan dampak yaitu peningkatan keterampilan dan peningkatan ekonomi keluarga. Kebanyakan dari peserta pengabdian yaitu mitra yang terdiri dari ibu-ibu rumah tangga, menghabiskan waktu luangnya dengan hal yang belum bermanfaat. Kegiatan pengabdian yang dilaksanakan mencoba memberikan solusi ditengah pandemi dengan memberdayakan masyarakat tersebut. Hakekat dari pemberdayaan adalah niat dari internal masyarakat yang dengan sadar secara internal dari diri sendiri (Simangunsong et al., 2019). Melalui masyarakaat yang berdaya maka, dapat meningkatkan ekonomi keluarga mandiri. Dengan masyarakat yang sudah diberdayakan Mitra dalam hal ini ibu-ibu rumah tangga dapat berkreasi dengan kemampuannya untuk memberikan sumbangsih kepada keluarga dalam bentuk peningkatan ekonomi. 
Setiap keluarga baik kecil maupun keluarga besar kesemuanya membutuhkan kebutuhan pokok yang harus dicukupi. Kondisi ekonomi yang berbeda-beda mengakibatkan setiap keluarga harus mencukupi kebutuhannya dengan saling menopang antara kepala keluarga dan juga peran ibu rumah tangga yang sifatnya adalah membantu. Usaha dalam menumbuhkan perekonomian keluarga tidak harus dengan semua anggota keluarga berperan aktif dalam bekerja. Hal yang dapat dilakukan adalah meningkatkan keterampilan dari masing-masing keluarga untuk turut andil dalam memajukan usaha guna memajukan ekonomi keluarga. Peningkatan ekonomi warga masyarakat seharusnya dapat ditingkatkan dengan cara mengembangkan dan meningkatkan kreativitas keterampilan yang dimiliki (Maesaroh \& Prasetyaningtyas, 2019). Hal yang sangat strategis dalam meningkatkan peran ekonomi keluarga adalah dengan meningkatkan peran dari anggota keluarga utamanya ibu-ibu rumah tangga. Keberadaan lbu-ibu yang bekerja dirumah sebenarnya mempunyai kekuatan yang sangat kuat dalam mengelola kebutuhan demi kesejahteraan keluarganya (Purnamasari et al., 2020). Pengabdian yang sudah dilakukan ini sengaja melibatkan peran dari ibu-ibu karena melalui peran aktif ini dapat memberikan usaha dan peluang untuk meningkatkan ekonomi yang sedang dibutuhkan oleh setiap anggota keluarga. Kegiatan pengabdian ini juga melibatkan kemampuan dalam mengolah sumber daya alam yang berada di sekitar perkampungan warga. Pengolahan sumber daya lokal dapat meningkatkan ekonomi warga tersebut (Sukesi et al., 2019).

\section{METODE PELAKSANAAN}

Kegiatan pengabdian ini telah dilaksanakan selama empat bulan yang dimulai dari bulan Agustus dan berakhir pada bulan Desember Tahun 2020. Kegiatan dilaksanakan secara periodik dan konsisten selama tiga hari dalam setiap minggunya yang dijadwalkan sesuai dengan kesepakatan dengan Mitra. Adapun Mitra yang dilibatkan dalam kegiatan ini terdiri dari ibu-ibu rumah tangga yang berjumlah 23 orang.

Metode kegiatan pengabdian yang telah dilaksanakan meliputi tiga hal yaitu pelatihan, penerapan dan pendampingan. Masing-masing kegiatan dilaksanakan secara bertahap dengan menerapkan tujuan utama yaitu menjadikan desa mitra yang berujung pada sentra pengrajin dan penghasil kerajinan melalui kerajinan rajutan. Secara visual dari metode kegiatan dapat dilihat sebagai berikut: 


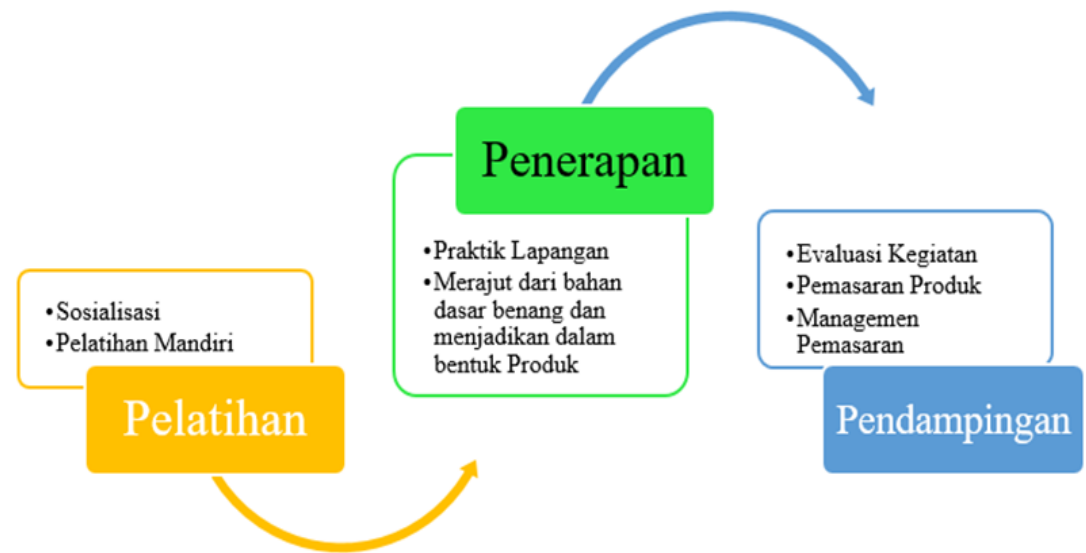

Gambar 1. Metode Pengabdian dalam Kegiatan PHP2D

Pelaksanaan dari metode pelatihan dilaksanakan secara bertahap langsung kepada masyarakat yang setiap pertemuannya dilaksanakan secara berpindah-pindah tempat. Adapun pelaksanaan dari metode pelatihan diantaranya terdapat kegiatan sosialisasi langsung kepada masyarakat sekitar. Hal yang disosialisasikan pada kegiatan ini meliputi upaya pengenalan kegiatan merajut yang secara khusus menambah keterampilan warga khususnya bagi ibu-ibu di waktu mengisi waktu luangnya dan dapat diinisiasi dalam memberikan gambaran pemasaran produk yang sudah dihasilkan. Adapun hal yang selanjutnya dilaksanakan langsung pelatihan mandiri tentang keterampilan merajut yang langsung di dampingi oleh tim pengabdi. Metode penerapan adalah lanjutan dari program pelatihan, yang langsung memberikan praktik kepada masyarakat. Adapun penerapan praktik merajut dengan menggunakan bahan yang sudah ada ditengah masyarakat. Selain merajut warga masyarakat juga diajarkan membuat dan menghasilkan benang yang dihasilkan dari kulit pohon bus yang endemik di Kabupaten Merauke. Selanjutnya dari hasil produk yang sudah dihasilkan dilakukan pembimbingan langsung untuk memasarkan guna memberikan bantuan tambahan penghasilan untuk membantu ekonomi warga.

\section{HASIL DAN PEMBAHASAN}

Hasil dari program yang telah dicapai ada beberapa keberhasilan yang didasarkan dari tujuan awal. Adapun masing-masing capaian dapat dilihat sebagai berikut:

\section{Pemahaman dan keterampilan}

Kegiatan yang sudah dilaksanakan dimulai dari metode pelatihan, penerapan dan pendampingan telah memberikan perubahan baik pemahaman dan keterampilan warga masyarakat mitra. Adapun berdasarkan dari prosentase kuantitatif hasil yang sudah dicapai dari kegiatan pengabdian ini dapat dilihat pada diagram berikut ini: 


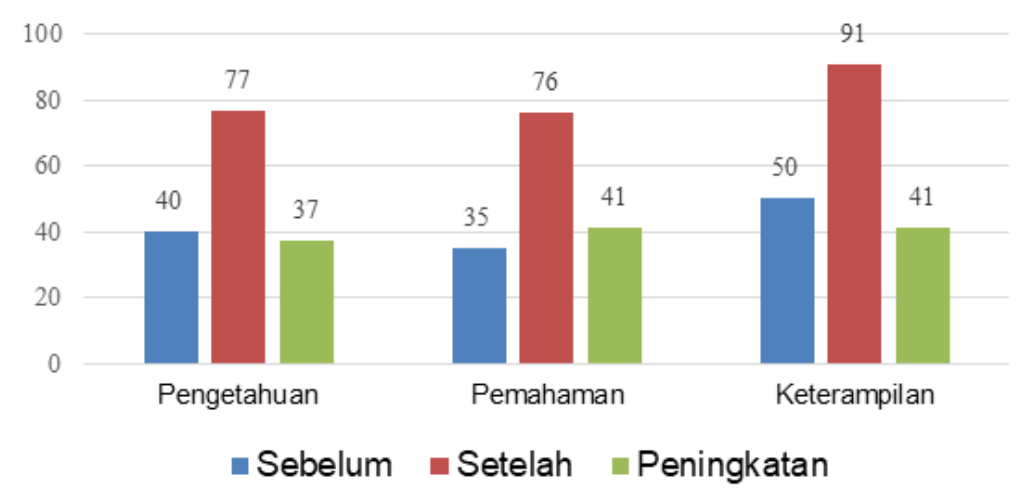

Gambar 2. Diagram Peningkatan Pemahaman dan Keterampilan Warga

Berdasarkan dari pemaparan diagram di atas dapat diketahui bahwa terjadi peningkatan pengetahuan, pemahaman dan keterampilan warga masyarakat yang telah mengikuti kegiatan ini. Rata-rata dari peningkatan yang sudah dicapai karena antusias warga masyarakat yang masih penasaran dengan kemampuan individu sebagai ibu rumah tangga yang sudah selayaknya aktif dalam kegiatan merajut. Selain itu kegiatan yang sudah dilakukan Mitra sebelumnya sudah mempunyai keterampilan dalam merajut.

\section{Terciptanya Produk}

Waktu yang telah digunakan sebagai implementasi dari penerapan ilmu dilaksanakan secara terus menerus sampai dihasilkannya produk. Mitra yang sudah mendapatkan keilmuan dari kegiatan ini selanjutnya melakukan tugas kerja secara mandiri hingga dihasilkan produk berupa benang hasil dari kulit kayu bus, produk yang dihasilkan memang masih dalam skala terbatas dikarenakan keterbatasan tenaga dan peralatan yang dapat memudahkan dalam memisahkan kulit kayu menjadi benang. Adapun hasil dari pemisahan serat kayu menjadi benang sebagai berikut:

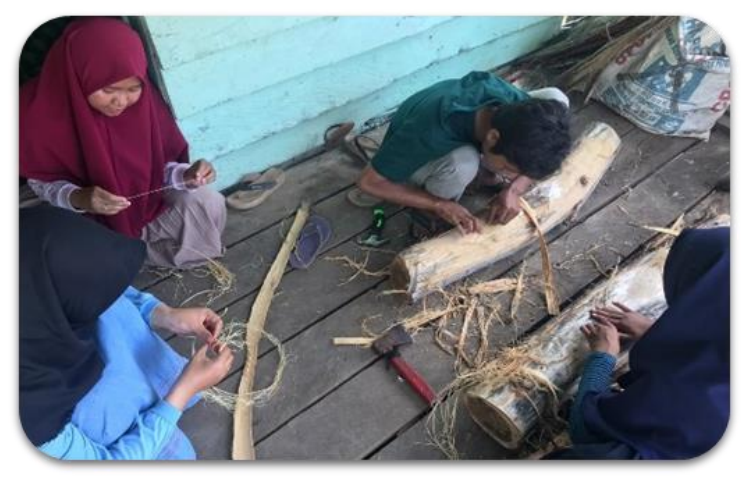

Gambar 3. Bahan Mentah Kulit Kayu Bus 


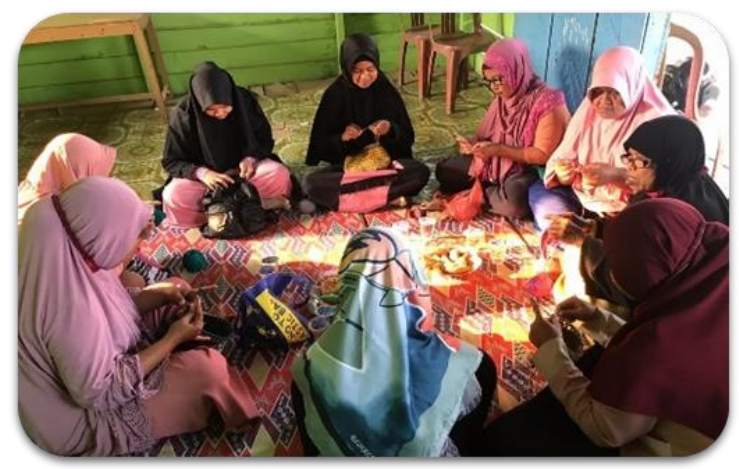

Gambar 4. Benang dari Serat

Benang yang sudah dihasilkan selanjutnya di olah dan digunakan dalam pembuatan produk yang mempunyai nilai harga tinggi dan dapat digunakan untuk kegiatan sehari-hari. Produk rajutan yang sudah familier ditengah masyarakat, diantaranya ada tas Noken Papua, rajutan songkok, rajutan penyambung masker untuk wanita berhijab, serta rajutan masker. Adapun hasil dari kegiatan pengabdian dari produk yang sudah dihasilkan oleh mitra sebagaimana pada gambar 5 dan 6 .

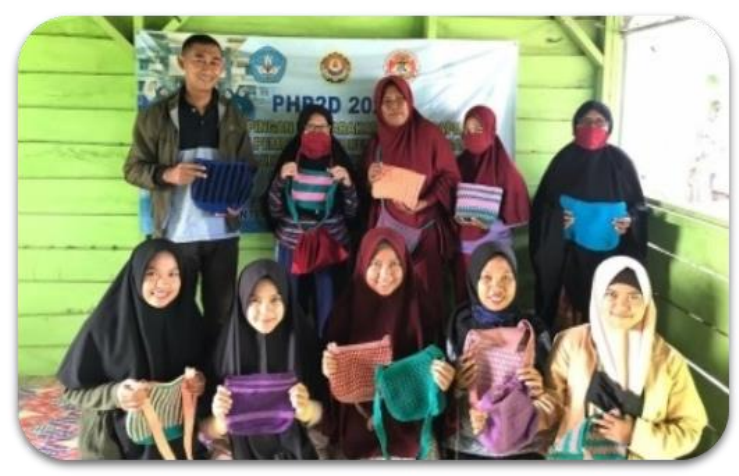

Gambar 5. Tas Noken

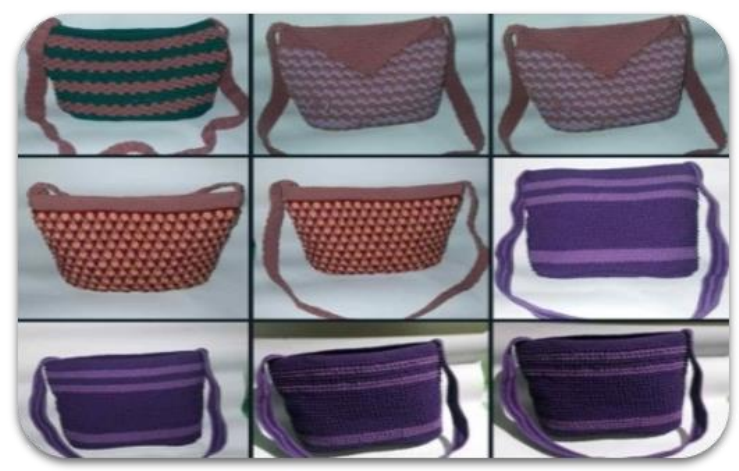

Gambar 6. Produk Tas 


\section{Pendampingan Pemasaran Produk}

Produk yang sudah dihasilkan oleh mitra selanjutnya dilakukan klasifikasi berdasarkan dari jenis dan kualitas produknya. Selanjutnya berdasarkan kesepakatan dengan mitra hasil produk yang sudah dihasilkan dapat di berikan harga sesuai dengan jenis rumitnya rajutan, jenis bahan yang dipakai serta dari asesoris yang digunakan pada produk. Berdasarkan dari kesepakatan warga produk-produk selanjutnya diberikan label nama sebagai brand hasil kerajinan serta di mulai dipasarkan melalui pemasaran tradisional dan juga online.

Selain pemasaran melalui tradisional yang menggunakan tempat untuk memasarkan produk. Dari kegiatan pengabdian ini Tim pengabdi juga memberikan bantuan dalam menyiapkan cara pemasaran yang lebih efektif, mengingat akan kecanggihan teknologi internet. Pemasaran online yang sudah dilaksanakan bersamaan dengan promosi produk di terapkan melalui media sosial facebook, instagram, aplikasi jual beli lokal. Melalui aplikasi ini dapat dengan mudah menawarkan, mempromosikan produk baru dan juga memberikan keluasaan pembayaran melalui cash maupun melalui transfer bank. Melalui pemasaran online ini secara langsung warga belajar dalam memahami kemajuan zaman yang serba cepat dan praktis baik dalam pemasaran produk maupun dalam memahami cara penjualan online lainnya. Adapun cara pemasaran online yang sudah diterapkan dapat dilihat pada gambar 7 dan 8 .

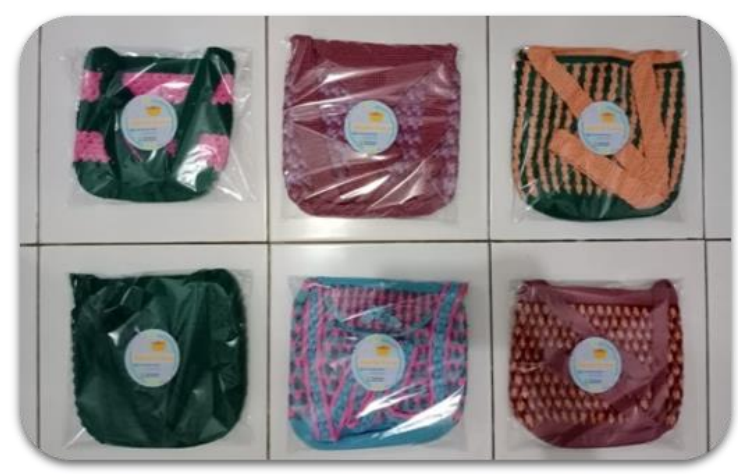

Gambar 7. Produk yang dipasarkan 


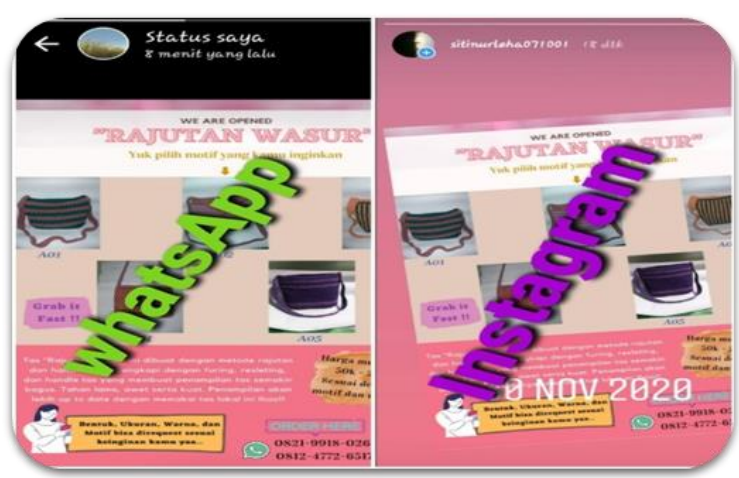

Gambar 8. Media Sosial yang digunakan

Semua produksi mulai proses awal, proses pembuatan hingga proses pemasaran telah dilaksanakan secara berkelanjutan hingga di batas waktu yang sudah ditentukan. Hal yang mulai digagas dari rangkaian kegiatan ini sebagai wujud nama dan tempat yang mudah dikenal dari produk hasil rajutan, maka sudah mulai diinisiasi dengan memberikan komunitas merajut dengan nama kitorang satu rajutan wasur. Hal ini memberikan semangat kepada mitra untuk lebih giat dalam bekerja dan melakukan konsistensi kegiatan dari hulu hingga hilir.

Proses yang telah berjalan dan sudah diterapkan kepada mitra selama ini bukanlah hal yang mudah dan berjalan lancar sesuai dengan rencana, berbagai kesulitan dan halangan telah dilalui dalam menerapkan program pengabdian. Hal yang sudah di laksanakan dapat memberikan hasil yang maksimal baik dari pihak pengabdi maupun dari pihak mitra (Sumarsono et al., 2019). Yang menjadi konsistensi dari hasil capaian adalah penggunaan waktu luang yang lebih produktif, banyaknya aktifitas produksi baik dari pembuatan benang, pembutan rajutan hingga aktifitas pemasaran produk. Capaian dari hasil akhir kegiatan ini adalah peningkatan sumber mata pencaharian warga serta menambah pendapatan keluarga khususnya saat pandemi Covid 19. keberhasilan dari program ini adalah hasil kerjasama dari semua tim pengabdi serta kerjasama baik dengan mitra.

\section{KESIMPULAN}

Upaya pendampingan Mitra dalam hal ini masyarakat non produktif kini telah menjadi masyarakat produktif. Implementasi ilmu yang didapatkan mahasiswa di lingkungan kampus dapat memberikan solusi pasti kepada masyarakat utamanya dalam membentuk usaha baru guna mendapatkan sumber mata pencaharian. Kegiatan yang dimulai dengan usaha pelatihan secara berkelanjutan telah menghasilkan produk yang siap untuk di pasarkan guna menambah penghasilan warga. Melalui kegiatan ini dapat memberikan solusi disaat pandemi khususnya dalam bidang ekonomi warga masyarakat yang berdampak langsung dari penyebaran Covid 19. 
Pada program selanjutnya diharapkan produk yang dihasilkan oleh mitra dapat memberikan sumbangsih ilmu dalam bentuk kerja nyata sebagai terapan ilmu dari dunia akademik kampus secara langsung kepada masyarakat.

\section{UCAPAN TERIMA KASIH}

Ucapan terima kasih disampaikan kepada Direktorat Jenderal Pendidikan Tinggi Pembelajaran dan Kemahasiswaan, Kementerian Pendidikan dan Kebudayaan Republik Indonesia yang telah bersedia memberikan kesempatan dan pendanaan kegiatan melalui Surat Keputusan Kontrak Nomor 228/E2/SPK/PHP2D/2020. Serta kepada Rektor Universitas Musamus Merauke yang telah memberikan izin melalui bidang kemahasiswaan serta mendukung penuh terlaksananya program pengabdian PHP2D, selanjutnya terima kasih juga disampaikan kepada masyarakat Mitra di Kampung Wasur khususnya dan di Kelurahan Rimba Jaya pada umumnya yang telah berperan aktif dalam kerjasama yang telah diberikan selama ini.

\section{DAFTAR RUJUKAN}

Maesaroh, I., \& Prasetyaningtyas, W. (2019). Kualitas Topi dengan Teknik Kait (Crochet). TEKNOBUGA: Jurnal Teknologi Busana Dan Boga, 7(2), 126-132. https://doi.org/10.1529/jtbb.v7i2.21354

Masiah, \& Adawiyah, S. R. (2020). Pelatihan Kerajinan Tas Rajut Bagi Remaja Putri Di Desa Mambalan. SELAPARANG Jurnal Pengabdian Masyarakat Berkemajuan, 3(2), 199-202. https://doi.org/10.31764/jpmb.v3i2.2199

Mona, N. (2020). Konsep Isolasi Dalam Jaringan Sosial Untuk Meminimalisasi Efek Contagious (Kasus Penyebaran Virus Corona di Indonesia). Jurnal Sosial Humaniora Terapan, 2(2), 117-125. https://doi.org/10.7454/jsht.v2i2.86

Purnamasari, V., Qurrata, V. A., \& Narmaditya, B. S. (2020). Pemberdayaan Wanita Melalui Peluang Usaha Dalam Peningkatan Ekonomi Lokal. Jurnal Graha Pengabdian, 2(1), 1-8. http://journal2.um.ac.id/index.php/jgp/article/view/12155

Rosdiana, A. (2018). Rajutan pada Kriya Seni Handmade. SULUH: Jurnal Seni Desain Budaya, 1(1), 69-80. https://ejournal.unisnu.ac.id/JSULUH/article/view/726

Simangunsong, H., Perwira, Y., \& Apriani, W. (2019). Pemberdayaan Ekonomi Masyarakat dalam Mewujudkan Desa Mandiri di Desa Banjar Jaya. TRIDARMA: Pengabdian Kepada Masyarakat (PkM), 2(1), 8-11. https://iocscience.org/ejournal/index.php/abdimas/article/view/534

Sukesi, T. W., Irjayanti, A., Hapsari, S. D., \& Efendi, A. (2019). Pemberdayaan Masyarakat Dalam Peningkatan Ekonomi Dengan Memanfaatkan Kearifan Lokal. Jurnal Pemberdayaan: Publikasi Hasil Pengabdian Kepada Masyarakat, 3(1), 111-116. https://doi.org/10.12928/jp.v3i1.635

Sumarsono, A., Nurcholis, \& Winarsih, S. (2019). Program Kemitraan 
Masyarakat: Pemanfaatan Pangan Lokal sebagai Sumber Asupan Gizi bagi Balita Prasejahtera Daerah Perbatasan di Kabupaten Merauke. Agrokreatif: Jurnal IImiah Pengabdian Kepada Masyarakat, 5(3), 258265. https://doi.org/10.29244/agrokreatif.5.3.258-265

Utami, D. A. B., \& Hidayah, D. U. (2019). Perancangan Tutorial Teknik-Teknik Dasar Merajut Berbasis Website. Jurnal SIFO Mikroskil, 20(2), 169176. https://mikroskil.ac.id/ejurnal/index.php/jsm/article/view/709

Vanda, Y., Ratnaningsih, R., \& Cahyono, S. A. (2015). Pemberdayaan Anggota PKK Kelurahan Gentan Sukoharjo. SEMAR (Jurnal IImu Pengetahuan, Teknologi, Dan Seni Bagi Masyarakat), 4(1), 55-61. https://doi.org/10.20961/semar.v4i1.838 